\title{
Investigating the effects of brand experience, trust, perception image and satisfaction on creating customer loyalty: A case study of laptop market
}

\author{
Samaneh Khalili ${ }^{a^{*}}$, Ahmad Rahchamani ${ }^{\mathrm{a}}$ and Masoumeh Sadat Abtahi ${ }^{\mathrm{b}}$
}

${ }^{a}$ Department of strategic Management, Qazvin Branch, Islamic Azad University, Qazvin, Iran

${ }^{b}$ Department of Humanities, Zanjan Branch, Islamic Azad University, Zanjan, Iran

\begin{tabular}{|c|c|}
\hline CHRON I C L E & A B S T R A C T \\
\hline $\begin{array}{l}\text { Article history: } \\
\text { Received May 15, } 2013 \\
\text { Received in revised format } \\
17 \text { August } 2013 \\
\text { Accepted } 18 \text { August } 2013 \\
\text { Available online } \\
\text { August } 202013 \\
\text { Keywords: } \\
\text { Perception image } \\
\text { Brand experience } \\
\text { Brand image } \\
\text { Brand satisfaction }\end{array}$ & $\begin{array}{l}\text { This paper presents an empirical investigation on the effects of brand experience, trust, } \\
\text { perception image and brand satisfaction on creating customer loyalty on Iranian laptop market. } \\
\text { The proposed study of this paper prepares a questionnaire in Likert scale and distributes it } \\
\text { among some university students in province of Qazvin, Iran. The implementation of structural } \\
\text { equation modeling for the proposed study of this paper has been accomplished based on } \\
\text { LISREL software. Cronbach alphas for experience, satisfaction, loyalty, trust and perception } \\
\text { from brand are calculated as } 0.71,0.83,0.76,0.69 \text { and } 0.86 \text {, respectively and they validate the } \\
\text { overall questionnaire. The results of the survey on testing various hypotheses indicate that } \\
\text { brand experience has positive and meaningful relationship with brand satisfaction, trust, } \\
\text { perception image and loyalty. In addition, satisfaction, perception image and trust have positive } \\
\text { meaningful with brand loyalty. }\end{array}$ \\
\hline
\end{tabular}

\section{Introduction}

Marketing academics and practitioners have repeatedly reported that consumers look for brands that provide them with unique and remarkable experiences. As a result, the concept of brand experience has become popular among marketers (Schmitt, 1999; Rajagopal, 1999; Rundle-Thiele \& Bennett, 2001). Zarantonello and Schmitt (2010), for instance, performed a survey with actual consumers tried to understand whether various consumers prefer different experiential appeals and whether experiential kinds moderate the relationships between brand attitude and purchase intention. They found that there were five kinds of consumers: hedonistic, action-oriented, holistic, inner-directed, and utilitarian consumers. Moreover, the relationship between behaviors and intentions was strongest for holistic consumers and it was the weakest for utilitarian consumers (Yoo \& Donthu, 2001). Yoo et al. (1998) examined how different characteristics of retail environments affected consumers' *Corresponding author.

E-mail address: sami_kh21@yahoo.com (S. Khalili) 
emotional responses in the shopping environment, and how these emotions, in turn, affect consumers' store behaviors. It also provided emerging research on in-store emotions by detecting through ethnographic interviews emotions created in the retail shopping environment that were not typically tapped by standard inventories of general human emotions. They reported that store characteristics had a pronounced impact on consumers' in-store emotions, and that these emotional experiences served as critical mediators in the store characteristics-store attitudes relationship. Yoo (2008) investigated the impacts of unconscious processing of Web advertisement (ad) by manipulating the level of attention devoted to the ad. Online advertisers have to be encouraged by the findings of this study and it was recommended that, upon exposure to Web ads, consumers experience priming caused by implicit memory and built a more favorable behavior towards the advertised brand regardless of the levels of attention they spend to the advertisements. van Birgelen et al. (2009) presented some new insights by analyzing consumer-related issues associated with distinct but connected package-related behaviors on beverage consumption. They reported that eco-friendly purchase and disposal decisions for beverages were associated with the environmental awareness of consumers and their eco-friendly behavior. In addition, consumers were willing to trade off almost all product attributes in favor of environmentally friendly packaging of beverages, except for price and taste. The non-supported hypothesis pertained to the expectation that believing in the positive impacts of own eco-friendly disposal actions would guide ecological disposal behavior. Perceived behavioral control may thus not end into actual disposal behavior.

Trasorras et al. (2009) evaluated customers' perceived value of professional services and how this affects satisfaction, loyalty and ultimately retention. They reported that there was a highly significant relationship between service and customer retention, quality and customer retention, image and customer retention, price and customer retention, and value and customer retention. Sivadas and Baker-Prewitt (2000) examined the relationship between service quality, customer satisfaction, and store loyalty. The results indicated that service quality affected relative attitude and satisfaction with department stores. Schmitt et al. (2009), in other study, distinguished various experience dimensions and built a brand experience scale, which included four dimensions including sensory, affective, intellectual, and behavioral (Aaker, 2009). Arnett et al. (2003) developed parsimonious retailer equity indexes using partial least squares analysis. Atilgan et al. (2005) performed an investigation on determinants of the brand equity in the beverage industry in Turkey. Anderson and Narus (1990) proposed a model of distributor firm and manufacturer firm working partnerships.

\section{The proposed model}

This paper presents an empirical investigation on the effects of experience, trust, perception image and satisfaction from brand on creating customer loyalty on Iranian laptop market. The proposed study of this paper prepares a questionnaire in Likert scale and distributes it among some university students in province of Qazvin, Iran. The implementation of structural equation modeling for the proposed study of this paper has been accomplished based on LISREL software. Fig. 1 demonstrates details of the proposed model.

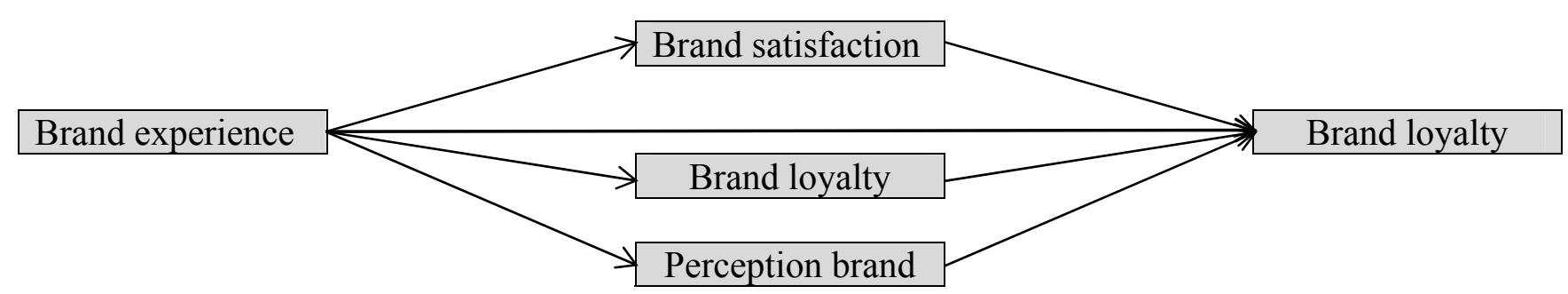

Fig. 1. The proposed model 
Based on the structure of the proposed study given in Fig. 1 we consider the following seven hypotheses,

1. Brand experience influences on brand satisfaction.

2. Brand experience influences on brand trust.

3. Brand satisfaction influences on brand loyalty.

4. Trust to a brand influences on brand loyalty.

5. Brand experience influences on brand loyalty.

6. Brand experience influences on perception image.

7. Perception image from a brand influences on brand loyalty.

The proposed study is performed among all 24,000 students who study in different areas at Islamic Azad University in Qazvin Branch. The sample size is calculated as follows,

$n=\frac{N \times z_{\alpha / 2}^{2} \times p \times q}{\varepsilon^{2} \times(N-1)+z_{\alpha / 2}^{2} \times p \times q}$,

where $N$ is the population size, $p=1-q$ represents the yes/no categories, $z_{\alpha / 2}$ is CDF of normal distribution and finally $\varepsilon$ is the error term. Since we have $p=0.5, z_{\alpha / 2}=1.96$ and $N=24,000$, the number of sample size is calculated as $n=264$. In terms of personal characteristics of the participants, 106 of them were male and the remaining 114 people were female. Fig. 2 shows other characteristics of the participants,

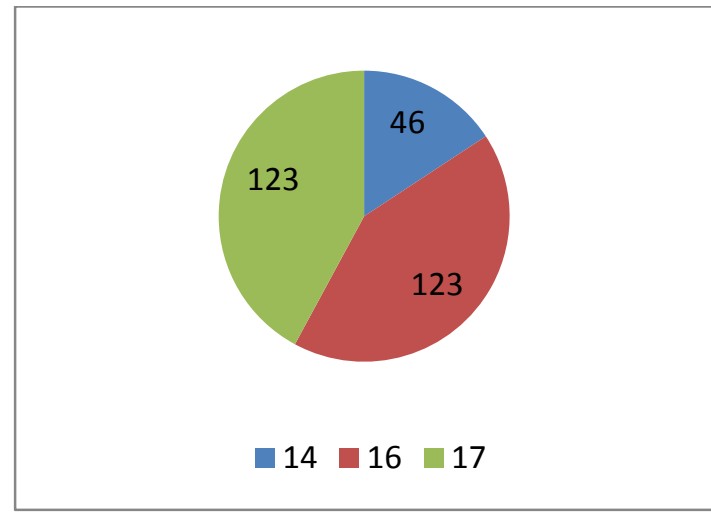

Years of education

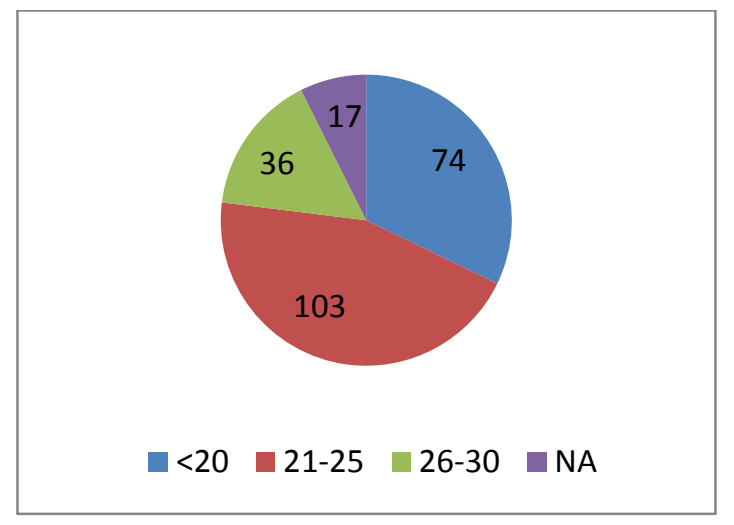

Age

Fig. 1. Personal characteristics of the participants

We have calculated Cronbach alpha on various components of the survey and Table 1 shows details of our findings,

\section{Table 1}

The summary of Cronbach alpha

\begin{tabular}{lccc}
\hline Variable & AVE & CR & Cronbach alpha \\
\hline Experience from brand & 0.82 & 0.86 & 0.71 \\
Satisfaction from brand & 0.87 & 0.74 & 0.83 \\
Brand loyalty & 0.91 & 0.82 & 0.76 \\
Trust to brand & 0.83 & 0.79 & 0.69 \\
Perception image & 0.86 & 0.88 & 0.86 \\
\hline
\end{tabular}

The results of Table confirm that all components of the survey maintain desirable values and they validate the results of our survey. We have also performed Kolmogorov-Smirnov test to make sure the normality of the data and the result is equal to 0.512 , which means the data are normally 
distributed when the level of significance is five percent. Next, we present details of statistical observations associated with LISREL software and Table 2 shows details of our survey.

Table 2

The summary of statistical observations

\begin{tabular}{lcc}
\hline Attribute & Value & Desirable value \\
\hline Chi-square/df & 2.13 & $<3$ \\
GFI & 0.91 & $>0.9$ \\
RMSEA & 0.074 & $<0.1$ \\
CFI & 0.95 & $>0.9$ \\
AGFI & 0.84 & $>0.80$ \\
NFI & 0.92 & $>0.90$ \\
NNFI & 0.94 & $>0.90$ \\
\hline
\end{tabular}

NFI: Normed Fit Index NNFI: Non Normed Fit Index CFI: Comparative Fit Index GFI: Goodness of Fit Index

AGFI: Adjustment Goodness of Fit Index RMSEA: Root Mean Square Error of Approximation

The results of Table 2 also imply that the outputs of LISREL method are trustable.

\section{The results}

In this section, we present the results of our survey. Fig. 3 shows details of our findings on applying structural equation modeling.

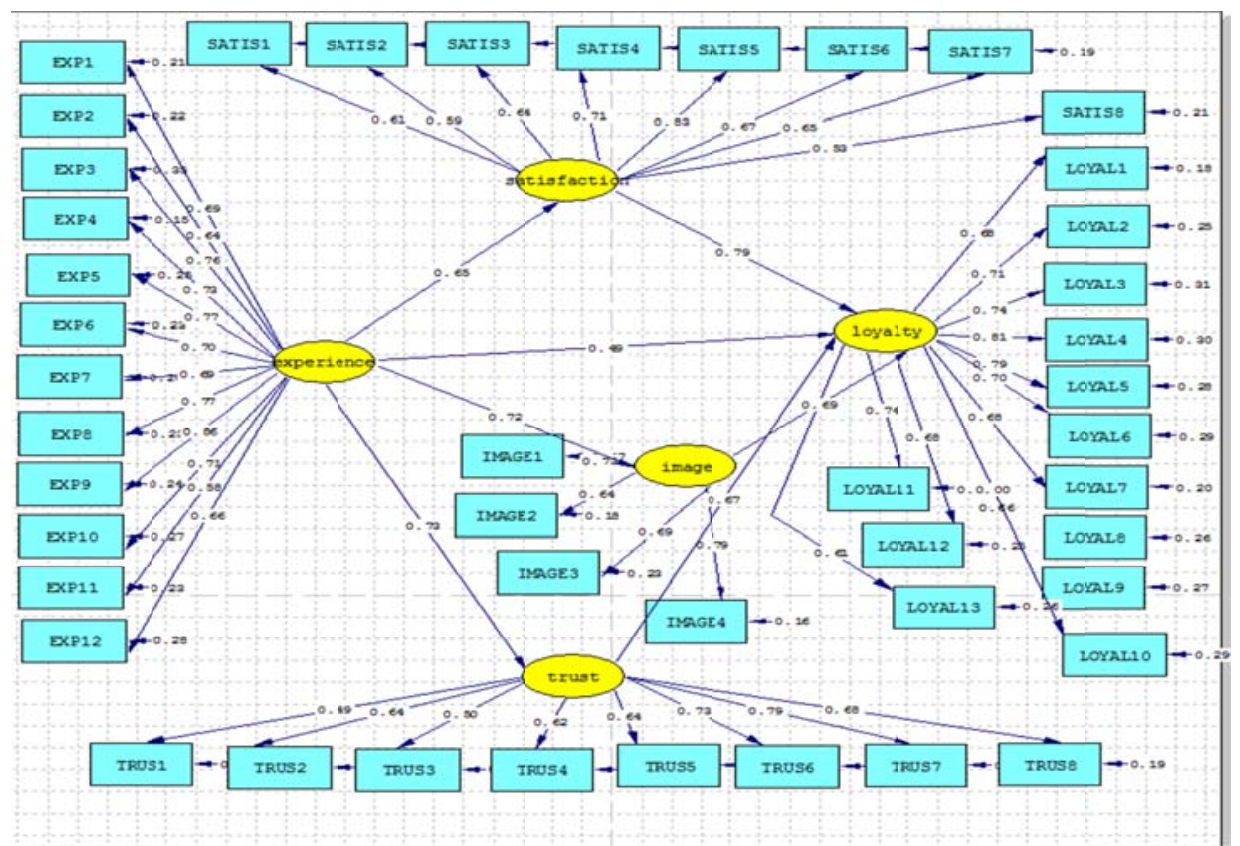

Fig. 3. The results of our proposed model

Based on the results of Fig. 3, we are now able to examine different hypotheses of this survey. Table 3 summarizes the results of our survey on testing various hypotheses,

Table 3

The results of testing various hypotheses

\begin{tabular}{lcc}
\hline Predicted variable & Path coefficient $(\beta)$ & t-student \\
\hline Brand experience & 0.49 & $12.39^{* *}$ \\
Satisfaction & 0.79 & $14.25^{* *}$ \\
Trust & 0.67 & $19.32^{* *}$ \\
Brand image & 0.69 & $10.25^{* *}$ \\
\hline
\end{tabular}


As we observe from the results of Table 4, hypotheses 3, 4, 5 and 7 are confirmed and we can conclude that brand satisfaction positively influences brand loyalty $(0.79)$, brand image influences brand loyalty (0.69), brand trust influences brand loyalty (0.67) and brand experience influences brand loyalty $(0.47)$.

\section{Conclusion}

In this paper, we have presented an empirical investigation to study the effect of brand experience on brand loyalty, brand satisfaction, brand trust and perception image. The proposed study has been accomplished among regular customers of laptop devices at Islamic Azad University in Iran. The study has implemented structural equation modeling to examine different hypotheses and the results have confirmed that brand experience has positive and meaningful relationship with satisfaction, trust, perception image and loyalty. In addition, satisfaction, perception image and trust have positive and meaningful relationship with brand loyalty. The results of this study have indicated that experience plays an important role on customer trust and customer retention. This means that the industry depends on people's experience and a good experience may lead to better purchase intention. Therefore, we may conclude that a vendor may succeed on this industry primarily by offering good quality products, which could build better image on the market. Since the market is highly competitive, it is recommended that only high quality products be offered to customers.

\section{Acknowledgment}

The authors would like to thank anonymous referees for constructive comments on earlier version of this paper, which have significantly contributed to the quality of the paper.

\section{References}

Aaker, D. A. (2009). Managing brand equity. SimonandSchuster. com.

Anderson, J. C., \& Narus, J. A. (1990). A model of distributor firm and manufacturer firm working partnerships. the Journal of Marketing, 42-58.

Arnett, D. B., Laverie, D. A., \& Meiers, A. (2003). Developing parsimonious retailer equity indexes using partial least squares analysis: a method and applications. Journal of Retailing, 79(3), 161170.

Atilgan, E., Aksoy, S., \& Akinci, S. (2005). Determinants of the brand equity: a verification approach in the beverage industry in Turkey. Marketing intelligence \& planning, 23(3), 237-248.

van Birgelen, M., Semeijn, J., \& Keicher, M. (2009). Packaging and proenvironmental consumption behavior investigating purchase and disposal decisions for beverages. Environment and Behavior, 41(1), 125-146.

Rajagopal, A. (1999). Thinking through emerging markets: Brand logics and the cultural forms of political society in India. Social text, 17(3), 131-149.

Rundle-Thiele, S., \& Bennett, R. (2001). A brand for all seasons? A discussion of brand loyalty approaches and their applicability for different markets. Journal of Product \& Brand Management, 10(1), 25-37.

Schmitt, B. (1999). Experiential marketing. Journal of Marketing Management, 15(1-3), 53-67.

Schmitt, B., Zarantonello, L., \& Brakus, J. (2009). Brand experience: what is it? How is it measured? Does it affect loyalty?. Journal of Marketing, 73(3), 52-68.

Sivadas, E., \& Baker-Prewitt, J. L. (2000). An examination of the relationship between service quality, customer satisfaction, and store loyalty. International Journal of Retail \& Distribution Management, 28(2), 73-82.

Trasorras, R., Weinstein, A., \& Abratt, R. (2009). Value, satisfaction, loyalty and retention in professional services. Marketing Intelligence \& Planning, 27(5), 615-632. 
Yoo, C., Park, J., \& MacInnis, D. J. (1998). Effects of store characteristics and in-store emotional experiences on store attitude. Journal of Business Research, 42(3), 253-263.

Yoo, B., \& Donthu, N. (2001). Developing and validating a multidimensional consumer-based brand equity scale. Journal of business research, 52(1), 1-14.

Yoo, C. Y. (2008). Unconscious processing of Web advertising: Effects on implicit memory, attitude toward the brand, and consideration set. Journal of Interactive Marketing, 22(2), 2-18.

Zarantonello, L., \& Schmitt, B. H. (2010). Using the brand experience scale to profile consumers and predict consumer behaviour. Journal of Brand Management, 17(7), 532-540. 